\title{
Trump's Steel and Aluminum Tariffs, National Security, and WTO Law
}

\section{Fengning $\mathrm{Li}^{*}$}

The US has invoked Article XXI of the GATT 1994 to justify its tariff measures on imports of steel and aluminum. However, the US' tariff measures are not imposed for the protection of the US "essential security interests" but for economic and trade reasons. They do not satisfy the conditions listed under Article XXI (b) (i) to (iii) and should not be justified by them. They should not be considered as either national security measures or safeguard measures, but as ordinary trade restriction measures that are inconsistent with the WTO rules and the US obligations. A panel or the Appellate Body not only has the jurisdiction to review this dispute, but is also capable of making findings and providing a recommendation. Even if the US has the discretion to impose tariff measures under Article XXI (b), whether it has been acted in good faith, is still subject to the WTO review. As regards the tariff measures, the US has not acted in good faith.

Keywords: Section 232, Steel and Aluminum Tariffs, GATT, Article XXI, Essential Security Interests, National Security, Safeguard Measures, Good Faith

* Associate Professor of International Economic Law at Wuhan University of Technology, China; Visiting scholar at George Mason University's Schar School of Policy and Government. LL.B. (Northwest Univ. of Political Science and Law of China), LL.M./Ph.D. (Wuhan). ORCID: https://orcid.org/0000-0002-7345-0454. Much gratitude is extended to Professor Eric Lee and reviewers of ChINA AND WTO Review. Special thanks also goes to Dr. Stuart Malawer who is the distinguished service professor of law and international trade at George Mason University for his continued help and support. Any errors remain the author's own. The author may be contacted at: lifn@whut.edu.cn /Address: Humanities and Law School of Wuhan University of Technology, No. 205 Luoshibei Road, Wuhan, P.R. China 430070. 


\section{INTRODUCTION}

Following the investigations carried out under Section 232 of the Trade Expansion Act of 1962, the US Department of Commerce released two reports on January 11 and 17,2018 , respectively. One is commonly referred to as the Steel Report, ${ }^{1}$ the other as the Aluminum Report. ${ }^{2}$ In these reports, the US Department of Commerce found that the imports of foreign steel and aluminum threatened to impair the US' national security and recommended a range of alternative actions, including global tariffs.

Based on the findings of these two reports, President Donald Trump issued two proclamations on March 8, 2018, that were later amended on March 22, 2018. In the proclamations, he decided to impose a 25 percent ad valorem tariff on imported steel articles and a 10 percent ad valorem tariff on aluminum articles, effective from March 23, 2018 with an unlimited duration. ${ }^{3}$

On April 5, 2018, China requested consultations over the above-described tariff measures (hereinafter US tariff measures), officially initiating a WTO dispute settlement procedure against the US. ${ }^{4}$ This dispute is referred to as United States - Certain Measures on Steel and Aluminum Products (DS544). India, Thailand, Russia, the European Union ("EU"), and Hong Kong (China) have requested to join the consultations. ${ }^{5}$ Shortly after, India, ${ }^{6}$ the EU, ${ }^{7}$ Canada, ${ }^{8}$ Mexico, ${ }^{9}$ Norway $^{10}$, Russia ${ }^{11}$, and Switzerland ${ }^{12}$ made separate requests to the WTO against the same US tariff measures. These eight disputes are still in the consultation process.

In its response to China's requests, the US invoked Article XXI of the GATT 1994 to justify its measures. It contended that "issues of national security are political matters not susceptible to review or capable of resolution by WTO dispute settlement." ${ }^{, 13}$ The US will probably put forward the same argument against the requests made by the other five WTO members.

The primary purpose of this research is to offer some thoughts on whether the US tariff measures can be justified by Article XXI and how the WTO should tackle this dispute. This article is composed of five parts including short Introduction and Conclusion. By analyzing the provisions of Article XXI, Part two tries to determine whether the US tariff measures are imposed to protect the US' "essential security interests." Part three asks to which category the US tariff 
measures belong under the WTO's legal framework. Are they national security measures, safeguard measures, or just ordinary trade restriction measures? Part four attempts to dissect how this dispute might be resolved by the Dispute Settlement Body ("DSB"). Are the US tariff measures capable of resolution by the WTO dispute settlement? In what manner and to what extent should the US tariff measures be reviewed? These questions are mainly addressed in this part.

\title{
II. Are the US Tariff Measures Imposed to Protect the US' Essential Security Interests?
}

\author{
Article XXI of the GATT 1994 provides:
}

"Nothing in this Agreement shall be construed:

(a) to require any contracting party to furnish any information the disclosure of which it considers contrary to its essential security interests; or

(b) to prevent any contracting party from taking any action which it considers necessary for the protection of its essential security interests

(i) relating to fissionable materials or the materials from which they are derived;

(ii) relating to the traffic in arms, ammunition and implements of war and to such traffic in other goods and materials as is carried on directly or indirectly for the purpose of supplying a military establishment;

(iii) taken in time of war or other emergency in international relations; or

(c) to prevent any contracting party from taking any action in pursuance of its obligations under the United Nations Charter for the maintenance of international peace and security."

Given that the US tariff measures are in dispute, it is reasonable to assume that the US would likely rely mainly on Article XXI (b) (ii) and/or (b) (iii) for justification. Based on the words of Article XXI (b), it is evident that, if the US tariff measures are to be justified, the following requirements should be satisfied. First, they should be either "carried on directly or indirectly for the purpose of supplying a military establishment" or "taken in time of war or other emergency in international relations." Second, they should be necessary for the protection of the US essential security interests. 


\section{A. Whether the US Tariff Measures are "Carried on Directly or Indirectly for the Purpose of Supplying a Military Establishment"?}

The Steel Report contended: "The US Department of Defense (DoD) has a large and ongoing need for a range of steel products that are used in fabricating weapons and related systems for the nation's defense. ${ }^{.14}$ However, it then admitted that the US military requirements for steel only represent about 3 percent of the US production. ${ }^{15}$ For aluminum, the estimated percentage of total US demand is omitted in the Aluminum Report, but it acknowledged that: "The US Department of Defense (DoD) and its contractors use a small percentage of US aluminum production. ${ }^{, 16}$ This small percentage, according to the US Secretary of Defense, is also only about 3 percent (of the US aluminum production). ${ }^{17}$

Therefore, steel and aluminum needed "for the purpose of supplying a military establishment" each represent about 3 percent of the US production. If this tiny percentage of the US production can meet its military requirements, it is hard to imagine that the imports of foreign steel and aluminum could pose a serious threat to the US national security. However, the US Department of Commerce still reached the conclusion in its reports that imports of steel and aluminum impose a threat to the US national security and recommended global tariffs. ${ }^{18}$

However, the US Secretary of Defense does not seem convinced. In response to Commerce Reports, he stated: "The US military requirements for steel and aluminum each only represent about three percent of US production. Therefore, [US Department of Defense ("DoD")] does not believe that the findings in the reports impact the ability of DoD programs to acquire the steel or aluminum necessary to meet national defense requirements." ${ }^{19}$ Contrary to the findings of two Commerce Reports, the US Secretary of Defense was confident that the US production of steel and aluminum is able to meet the US national defense requirements.

The WTO Ambassador of China offered more details on this issue on May 8, 2018, at the General Council meeting. He stated: "The steel used by the US defense industry only accounts for $3 \%$ of the domestic steel consumption of the US, while the output of the US steel industry equals to $84 \%$ of its domestic consumption, that is, roughly 28 times of its defense demand. ${ }^{20}$ This further shows that the US' domestic industry is sufficiently strong to meet its national defense demand. 
Thus, as the US' domestic industry can easily meet the US national defense requirements, the US tariff measures cannot be considered as necessary actions "carried on directly or indirectly for the purpose of supplying a military establishment." ${ }^{, 21}$ There is simply no strong link between the US national defense requirements (or military establishment) and the imports of foreign steel and aluminum. The US Department of Commerce lacks concrete and direct evidence to prove its conclusions.

\title{
B. Whether the US Tariff Measures are "Taken in Time of War or other Emergency in International Relations"?
}

We proceed to determine whether the US tariff measures are "taken in time of war or other emergency in international relations." Because the two Commerce Reports are very similar, we will take the Steel Report as an example. With respect to war, the Steel Report stated:

\begin{abstract}
Should the US once again experience a conflict on the scale of the Vietnam War, steel production capacity may be slightly insufficient to meet national security needs. But if the US were to experience a conflict requiring the production increase seen during the Second World War, the existing domestic steel production capacity would be unable to meet national security requirements. ${ }^{22}$
\end{abstract}

According to these statements, steel production capacity would be only slightly insufficient to meet national security needs if the US once again fights an armed conflict on the scale of the Vietnam War. However, because it is currently not involved in a war that is on or even close to the scale of the Vietnam War, we can assume that the existing domestic steel production capacity is able to meet the US national security requirements, which the DoD has already confirmed in its response to the Commerce Reports. ${ }^{23}$

Regarding "other emergency in international relations," the text "suggests a preliminary answer: "emergency in international relations" is not used as a stand-alone term but as an annex to the term war. Thus the term "emergency in international relations" certainly then must cover those hostile interactions between states which, although short of being a 'war,' constitute an armed conflict" ${ }^{24}$ or face a similar international political confrontation. However, we were unable to 
find any other emergency concerns except these three factors stated in the Steel Report: "displacement of domestic steel by excessive imports and the consequent adverse impact on the economic welfare of the domestic steel industry, along with global excess capacity. ... "25 Apparently, these three factors are all commercial matters and have nothing to do with war-like conflicts or international political tensions. Thus, the US tariff measures were not imposed because the US is in the midst of war or any other emergency in international relations. Rather, they were imposed due to economic reasons.

It is worth noting that there was a very similar case under the GATT 1947 that shared, in principle, the same features as this dispute. In 1975, Sweden introduced a global import quota system for certain footwear. The Swedish government stated, inter alia, that:

The decrease in domestic production has become a critical threat to the emergency
planning of Sweden's economic defense as an integral part of the country's
security policy. This policy necessitates the maintenance of a minimum domestic
production capacity in vital industries. Such a capacity is indispensable in order
to secure the provision of essential products necessary to meet basic needs in case
of war or other emergency in international relations. ${ }^{26}$

In the discussion of this measure in the GATT Council, "Many representatives ... expressed doubts as to the justification of these measures under the General Agreement. ... Many delegations reserved their rights under the GATT and took note of Sweden's offer to consult." ${ }^{27}$ The GATT Council concluded that the Swedish measure was an example of abuse and misuse of the GATT security exceptions. $^{28}$

The US tariff measures can be interpreted as the US version of Sweden's footwear case. In Sweden's footwear case, however, the Swedish government knew that its measure was inconsistent with Article XXI, so it did not invoke Article XXI for justification. Instead, it considered that its measure was taken in conformity with the 'spirit' of Article XXI. As commented by the US, this confirms that the WTO members in fact have strived to limit their invocations of Article XXI to situations in which they consider this as appropriate. ${ }^{29}$ Yet, in this dispute, the US did not hesitate to invoke Article XXI for justification, despite the similarity of its case to Sweden's footwear case. If the US is serious about its 
comment, it should also consider limiting its invocations of Article XXI because its measures are not taken in a manner in conformity with the provisions of Article (b)(iii).

\title{
C. Whether the US Tariff Measures are "Necessary for the Protection of its Essential Security Interests"?
}

Although titled 'security exceptions' and often quoted as "national security exceptions," the actual phrase that Article XXI of the GATT 1994 uses to address this issue is "essential security interests." In other words, Article XXI does not cover all national security concerns, only "essential security interests." Article XXI does not define "essential security interests," but the following statements from one of the US drafters of the original Draft Charter can help us to understand it:

\begin{abstract}
We recognized that there was a great danger of having too wide an exception and we could not put it into the Charter, simply by saying: 'by any Member of measures relating to a Member's security interests,' because that would permit anything under the sun. Therefore we thought it well to draft provisions which would take care of real security interests and, at the same time, so far as we could, to limit the exception so as to prevent the adoption of protection for maintaining industries under every conceivable circumstance. ... There must be some latitude here for security measures. It is really a question of balance. We have got to have some exceptions. We cannot make it too tight, because we cannot prohibit measures which are needed purely for security reason. On the other hand, we cannot make it so broad that, under the guise of security, countries will put on measures which really have a commercial purpose.
\end{abstract}

Therefore, according to the drafters, "not any interest will qualify under this exception. The interest must relate genuinely to 'security' and be 'essential.' Purely economic interests or security interests of minor importance would not qualify.",31

However, the meaning of 'national security' that the US Department of Commerce applied to conduct the steel and aluminum investigations is much broader. Although these investigations were conducted under Section 232 of the Trade Expansion Act, the definition of 'national security' is not contained in this legislation. Congress in Section 232 simply determined that 'national security' 
includes but is not limited to 'national defense' requirements. ${ }^{32}$ In 2001, however, the US Department of Commerce dramatically expanded the meaning of 'national security.' In one of its regulations, it determined that 'national defense' includes both defense of the US directly and the "ability to project military capabilities globally.", It also concluded that "in addition to the satisfaction of national defense requirements, the term 'national security' can be interpreted more broadly to include the general security and welfare of certain industries, beyond those necessary to satisfy national defense requirements, which are critical to the minimum operations of the economy and government. ${ }^{, 34}$

Accordingly, these wide interpretations allow the US Department of Commerce to take into account economic welfare and other factors not necessary for the protection of its essential security interests. Although this appears to be inconsistent with the provisions of GATT Article XXI, thanks to the US Department of Commerce, Section 232 can now be served to protect the US steel and aluminum industries in the name of national security.

Take the Steel Report for example! The reasons it listed for national security threats included: (a) "steel is important to US national security"; (b) "imports in such quantities as are presently found adversely impact the economic welfare of the US steel industry"; (c) "displacement of domestic steel by excessive quantities of imports has the serious effect of weakening our internal economy"; and (d) "global excess steel capacity is a circumstance that contributes to the weakening of the domestic economy." ${ }^{35}$ Reason (a) does relate to national security concerns. However, the above analysis shows that evidence to support the conclusion is lacking. In exception, all other reasons are purely economic and concern trade factors. Thus, the steel and aluminum tariffs were not imposed "purely for security reasons," but rather for a 'commercial purpose.' They were not imposed to protect the US' essential security interests but to protect its domestic industries. That is the real purpose of the US tariff measures.

In addition, as the well-known "President of Twitter," Trump's tweets also provide some clues about their real purpose. President Trump has been particularly interested in American steel and aluminum industries since he began running for president in 2015. From June 2015 to the end of April 2018, Trump had posted about 20 steel-focused tweets. He either blamed unfair trade or bad policies for decimating the US steel and aluminum industries or vowed to protect and build 
them. On March 1, 2018, for example, he tweeted: "Our Steel and Aluminum industries (and many others) have been decimated by decades of unfair trade and bad policy with countries from around the world. We must not let our country, companies and workers be taken advantage of any longer. We want free, fair and SMART TRADE!, ${ }^{36}$ Another tweet worth more attention, on March 8, 2018, right before Mr. Trump officially issued the steel proclamation, he tweeted: "Looking forward to 3:30 P.M. meeting today at the White House. We have to protect \& build our Steel and Aluminum Industries while at the same time showing great flexibility and cooperation toward those that are real friends and treat us fairly on both trade and the military." ${ }^{37}$ These tweets clearly show that the real intents of the US tariff measures are to "protect \& build [American] steel and aluminum industries" and to obtain a "positive trade balance."

\section{What kind of Trade-Related Measures do THE US TARIFF MEASURES REPRESENT?}

Because the US steel and aluminum tariffs provide protection for domestic industries and involve tariffs, they are not consistent with the WTO rules, especially Article II of the GATT 1994. However, in which category do they belong under the WTO's legal framework?

\section{A. Are They National Security Measures?}

The US contends that they are national security measures because the steel and aluminum tariffs are imposed "pursuant to Section 232 of the Trade Expansion Act of 1962, under which the President determined that tariffs are necessary to adjust imports of steel and aluminum articles that threaten to impair the national security of the United States. ${ }^{, 38}$

Yet, the above analysis has already stated that the US tariff measures do not conform to the provisions of Article XXI of the GATT 1994. The fact that the United States initiated and conducted an investigation under its domestic national security legislation does not necessarily mean that the tariffs imposed on imports of steel and aluminum at the end of that process are "national security measures" or "essential security interests measures" within the meaning of Article XXI. 
Therefore, these measures cannot be treated as real national security measures, or to be precise, real, essential security measures in accordance with Article XXI of the GATT 1994. If addressing these issues from the perspective of security concerns, they are illegal or fake essential security measures under the legal framework of the WTO.

\title{
B. Are They Safeguard Measures or other Trade Restriction Measures?
}

Many WTO members disagree with the US' claims and believe that the steel and aluminum tariffs are safeguard and/or emergency measures. On March 26, 2018, China requested consultations under Article 12.3 of the Agreement on Safeguards with respect to the above-mentioned US tariff measures. ${ }^{39}$ In the request, China took the view that the US steel and aluminum tariffs were safeguard measures, even though they were categorized as national security measures. ${ }^{40}$ The ambassadors of China further explained:

\begin{abstract}
The purpose of the Section 232 measures by the US against steel and aluminum products according to our understanding is not to protect so-called 'national security' of the US, but rather it serves to protect the commercial interests of the domestic industries. As such, such measure should be considered as safeguard measures under the Agreement on Safeguards, and meet necessary requirements as set in that agreement. ${ }^{41}$
\end{abstract}

In response to China's accusations, the US simply disagreed and stated: "The tariffs imposed pursuant to Section 232 are not safeguard measures. ... The United States did not take action pursuant to Section 201 of the Trade Act of 1974, which is the law under which the United States imposes safeguard measures." ${ }^{42}$

The EU and India also made similar requests under Article 12.3 of the Agreement on Safeguards over the US tariff measures. ${ }^{43}$ The EU seemed to agree with China, but stressed that the US tariff measures were, 'in essence,' safeguard measures. ${ }^{44}$ India further pointed that the US tariff measures were "emergency action[s]/safeguard measure[s] within the meaning of Article XIX of the GATT 1994 and the Agreement on Safeguards. ${ }^{, 45}$ Scholars are also unable to reach a consensus. Some regard them as safeguard measures or emergency measures, while others believe they are a mix of the two. Another group of scholars are uncertain but know enough to claim that they are not safeguard measures. ${ }^{46}$ So, 
why is there so much controversy or uncertainty?

First, to answer this question, it may be because the US justifies this whole matter under the name of national security concerns instead of safeguard measures or other trade restriction measures. The investigations, the issuance of the Commerce Reports and the presidential proclamations, and the national security threats analysis were all undertaken pursuant to Section 232 of the Trade Expansion Act of 1962, which governs national security issues, instead of Section 201, which regulates safeguard measures. All these efforts were carefully designed, intentionally implemented, and well decorated under the guise of national security. As a result, they appear to be classified as national security measures. This explains why these measures can hardly fill other categories, such as safeguard or emergency measures, anti-dumping measures, countervailing measures, etc.

Second, it may also be because safeguard measures have their unique natures. Professor Peter Van den Bossche rightly pointed: "Safeguard measures are measures, otherwise inconsistent with Articles II or XI of the GATT 1994, which are justified under the economic emergency exception provided for in Article XIX of the GATT 1994 and the Agreement on Safeguards." ${ }^{47}$ Thus, when referring to safeguard measures, they are legitimate; they are trade restriction measures, but can be justified by relevant provisions of WTO Agreements.

The WTO case law also confirms this understanding. For example, in Indonesia-Iron or Steel Products, the panel stated:

\footnotetext{
One of the defining features of the measures provided for in Article XIX: 1(a) (i.e. safeguard measures) is the suspension, withdrawal, or modification of a GATT obligation or concession that precludes a Member from imposing a measure to the extent necessary to prevent or remedy serious injury, in a situation where all of the conditions for the imposition of a safeguard measure are satisfied. ${ }^{48}$
}

Therefore, only in a situation where "all of the conditions for the imposition of a safeguard measure are satisfied" can a measure constitute a safeguard measure and then be executed as a safeguard measure. When China and other countries asserted that the US steel and aluminum tariffs were 'safeguard measures,' they inadvertently admitted that these measures were legitimate and could be justified by Article XIX of the GATT 1994 and the Agreement on Safeguards. That is 
certainly not what China, the EU, and India meant when they filed the requests.

Moreover, according to the WTO case law, in order to determine whether or not a safeguard measure can be applied, two basic inquiries need to be conducted in the beginning: (1) "is there a right to apply a safeguard measure?"; and (2) "if so, has that right been exercised, through the application of such a measure, within the limits set out in the treaty?" ${ }^{49}$ Regarding this dispute, is there a right for the US to apply a safeguard measure under the current circumstances? This is difficult to determine now because the US has not conducted a safeguard measure investigation. It is also unknown if all of the conditions for imposing a safeguard measure are satisfied. In practice, both the steel and aluminum investigations were conducted to address so-called national security threats, not economic emergency concerns. As a result, evidence is insufficient to answer these questions.

However, the US may not have the right to apply safeguard measures because not all the conditions were satisfied or the steel and aluminum tariffs were not imposed within the limits. If so, the steel and aluminum tariffs do not represent safeguard measures, i.e., they are not legitimate. This is why it may sound strange when China and other countries claimed that the US steel and aluminum tariffs were safeguard measures. Later when Canada requested consultations with the US, it contended: "The measures at issue appear to constitute or amount to emergency actions or safeguard measures adopted and implemented in a manner inconsistent with the substantive and procedural obligations of the Agreement on Safeguards and the GATT 1994. ${ }^{, 50}$ These statements are more precise than China's.

In short, the US tariff measures in dispute are neither national security measures, nor safeguard measures (to be precise, nor legitimate safeguard measures). Needless to say, they are neither anti-dumping measures, nor countervailing measures. These are simply ordinary trade restriction measures that are inconsistent with the WTO rules and cannot be authorized by any WTO provision. 


\section{How Should the US Tariff Measures be RESOLVED BY THE DSB?}

Because the national security factors that the US applied to impose its steel and aluminum tariffs were not "essential security interests" but economic and trade reasons, the US tariff measures shall not be justifiable in accordance with the provisions of Article XXI of the GATT 1994. Any attempt to seek exemption by invoking Article XXI is an abuse of that right and should not be encouraged. Because the US has already invoked Article XXI for justification, however, does the DSB have the authority to review the dispute? If it does, in what manner and to what extent can the US tariff measures be reviewed?

\section{A. Are the US Tariff Measures Capable of Resolution by the WTO Dispute Settlement?}

The US has long held the view that as Article XXI is a self-judging provision, its invocation is not subject to review by the DSB.$^{51}$ In its response to China's request for consultation, the US expressed the same idea:

Issues of national security are political matters not susceptible to review or capable of resolution by WTO dispute settlement. Every Member of the WTO retains the authority to determine for itself those matters that it considers necessary to the protection of its essential security interests, as is reflected in the text of Article XXI of the GATT $1994{ }^{52}$

However, the above US allegations seem slightly different from the opinion that the US held in Russia-Measures Concerning Traffic in Transit (DS512) with respect to Article XXI. ${ }^{53}$ Responding to the Panel's and Russia's questions, the US stated: "The Panel does possess jurisdiction over this dispute, but that the dispute presents a non-justiciable issue for which the Panel cannot make findings or provide a recommendation." ${ }^{, 54}$ The US maintained that the panel or the Appellate Body has the ability or jurisdiction to organize and hear Article XXI disputes, but the panel or the Appellate Body lacks the authority to review the invocation of Article XXI and may not provide findings or a recommendation because no finding of a WTO inconsistency may be made. ${ }^{55}$

The above arguments not only contradict each other, but also lack a solid 
legal basis. First, the argument that Article XXI is a self-judging provision is not accurate and precise because subparagraphs (a), (b) and (c) regulate different situations. Article XXI (c) is by no means self-judging. Article XXI (a) and (b) both use the words 'it considers,' which may suggest they are self-judging, but the phrasing Article XXI (b) uses is quite different from that of Article XXI (a). Specifically, Article XXI (b) restricts the words 'it considers' with the phrase "necessary for the protection of its essential security interests," as well as three requirements listed in Article XXI (b)(i) to (iii). This indicates that the conditions listed under Article XXI (b)(i) to (iii) "have a distinct meaning of their own; and that no such qualifying terms are listed under Article XXI (a) implies that the list under [Article XXI (b)] (i) to (iii) was supposed to restrict the broad discretion granted by the introductory sentence. ${ }^{, 56}$ In other words, this shows that "the intention of the drafters of the GATT 1994 was not to allow for reliance on security exceptions in any circumstance, but only in those circumstances specifically listed in subparagraphs (i) to (iii) of Article XXI (b)., ${ }^{, 57}$

This understanding complies with the purpose of Article XXI, which attempts to strike a balance between the interests of free trade and national security. It also reflects the intentions of the drafters, as noted above. In addition, the newly signed TPP/CPTPP, the trade pact that the US once led but later withdrew, also contains an essential security clause. However, its Article 29.2 (Security Exceptions) provides no conditions like the ones under GATT Article XXI (b)(i) to (iii). ${ }^{58}$ It may be because the US and other eleven countries realized that these conditions would restrict a state's discretion to determine what is necessary for the protection of its security interests, they deliberately removed them. This reconfirms the above findings.

Therefore, it is reasonable to say that Article XXI (b) is not an entirely selfjudging provision or even a justifiable provision, at least not like Article XXI (a). It should be thus exercised with the conditions listed in Article XXI (b)(i) to (iii). This suggests that its invocation by a defending WTO member is still subject to the WTO review. Thus, the US' arguments that Article XXI as a whole is self-judging and its invocation is not subject to the WTO review are not well established or convincing.

Second, Article XXI does not provide an exception to the rules of the jurisdiction laid down in the Dispute Settlement Understanding ("DSU"). Nor do 
any of those rules provide any basis for arguing that Article XXI of the GATT 1994 is to be regarded as non-justiciable. ${ }^{59}$ The phrase "nothing in this Agreement" in the chapeau of Article XXI may suggest that the invocation of Article XXI is not subject to other substantial rules or obligations of the GATT 1994. However, 'this Agreement' refers only to the GATT 1994 and not to any other agreement. In other words, in the WTO context, measures taken under Article XXI of the GATT 1994 still have to be bound by the WTO Agreement and its annexes, including, in particular, the DSU. The DSU provides a single, coherent system of rules and procedures for a dispute settlement. These are applicable to disputes arising under any of the covered agreements, ${ }^{60}$ including the GATT 1994, particularly in relation to its Article XXI. On the other hand, the DSU "contains no security exception and applies equally in respect of any provision of the covered agreements, subjecting these to the compulsory jurisdiction which the DSU has created." ${ }^{, 61}$ Therefore, neither Article XXI nor any other provision has the effect of excluding the jurisdiction of the DSB.

Third, the US is wrong in that any finding of a WTO inconsistency may be made under these circumstances. According to Article XVI:4 of the WTO Agreement, each member shall ensure the conformity of its laws, regulations, and administrative procedures with its obligations as provided in the annexed agreements. Section 232 of the Trade Expansion Act of 1962 and its associated regulations, however, "appear to be 'as such' inconsistent with Articles I:1 and II:1 of the GATT 1994 and does not appear to be justifiable under Article XXI:(b) of the GATT 1994 because they require the US to account for economic welfare and other factors that are not necessary for the protection of its essential security interests, in a manner that is inconsistent with Article XVI:4 of the WTO Agreement." ${ }^{, 62}$

Moreover, as argued by India and Mexico in their consultation requests, a nonviolation claim could also be applied to the US tariff measures. ${ }^{63}$ Specifically, the benefits accruing to China and other members directly and indirectly under the GATT 1994 are nullified and impaired as a result of the application of the US tariff measures within the meaning of Article XXIII:(b) of the GATT $1994 .^{64}$ Surprisingly, the US seems to recognize this argument. In United States - Trade Measures Affecting Nicaragua, the US contended that a measure not conflicting with obligations under the GATT "could be found to cause nullification and 
impairment and that an invocation of Article XXI did not prevent recourse to the procedure of Article XXIII." ${ }^{, 65}$ Therefore, under each circumstance, either the panel or the Appellate Body is capable of providing findings and a recommendation.

Lastly, as far as this dispute is concerned, the US' arguments seem dangerous because they can potentially damage the integrity and credibility of the WTO. They run against the objectives of the DSU as well as the entire multinational trade system. Following its arguments, "a WTO Member, rather than the WTO dispute settlement bodies, would be deciding unilaterally the outcome of a dispute." ${ }^{, 66}$ As a result, even if the Panel is established to adjudicate this dispute, it would likely make no recommendations simply because the US has invoked Article XXI for justification.

If this were allowed to happen, undoubtedly, it would provide a precedent for other countries to take similar trade actions under the GATT Article XXI. ${ }^{67}$ For example, China could argue that its export controls regarding minerals and its Internet rules exist for the protection of its national security. ${ }^{68}$ The US could be encouraged to invoke security exceptions more frequently to protect its domestic industries or corporate interests. Other countries, especially economically powerful states, would follow this lead. Ultimately, it could damage the entire WTO regime.

For the above reasons, there are no credible and convincing arguments that could support the US' allegation. Therefore, this dispute is not subject to review by the DSB. If a panel is established in this dispute, it certainly has jurisdiction to adjudicate it.

\section{B. In What Manner and to What Extent should the US Tariff Measures be Reviewed?}

Despite the above findings, the question - in what manner and to what extent can the DSB review an Article XXI (b) dispute - remains unsettled. The GATT and the WTO have not provided a conclusive answer on the reviewability of Article XXI (b) defenses. ${ }^{69}$ Differences of opinion regarding this matter have emerged. ${ }^{70}$ However, the pertinence of a good faith standard seems widely accepted. ${ }^{71}$

First, the 'good faith' principle is widely recognized by the laws and practice of the WTO. Several WTO provisions refer specifically to 'good faith' (e.g., Articles 3.10 and 4.3 of the DSU, as well as Articles 24, 48.2, and 58(c) of the TRIPs Agreement). ${ }^{72}$ Some WTO provisions are considered to be applications of 
the 'good faith' principle. For instance, in United States - Import Prohibition of Certain Shrimp and Shrimp Products (DS58), the Appellate Body Report stated: "The chapeau of Article XX is, in fact, but one expression of the principle of good faith." ${ }^{, 73}$ Many aspects of 'good faith' - namely, pacta sunt servanda, abuse of rights and discretion, as well as estoppel and acquiescence - and negotiations in 'good faith' have been addressed or applied in the panel's or the Appellate Body's reports. ${ }^{74}$ Moreover, the panels and the Appellate Body repeatedly stated that the 'good faith' principle, at once a general principle of law and international law, controls the exercise of rights by states. ${ }^{75}$ This suggests that good faith may underlie the WTO agreements as a whole. ${ }^{76}$ This applies in respect of all WTO provisions, including Article XXI (b).

Second, when interpreting the text of Article XXI (b), it needs to be acted in 'good faith.' The DSU provides a solid legal basis for this. According to Article 3(2) of the DSU, the members recognize that the WTO dispute settlement system "serves to preserve the rights and obligations of Members under the covered agreements, and to clarify the existing provisions of those agreements in accordance with customary rules of interpretation of public international law.",77 Many WTO cases have stated that the "general rule of interpretation" contained in Article 31 of the Vienna Convention of Law of Treaties ("VCLT") has attained the status of "customary or general international law." 78

Article 31 of VCLT provides: "A treaty shall be interpreted in good faith in accordance with the ordinary meaning to be given to the terms of the treaty in their context and in the light of its object and purpose." Therefore, the good faith standard should be generally applied whenever WTO agreements need to be interpreted. Because the language of Article XXI (b) is so broad and ambiguous, it needs to be clarified in accordance with Article 31 of the Vienna Convention (i.e., to be interpreted in good faith).

Third, members are also obliged to carry out their WTO obligations in good faith. Panels and the Appellate Body have frequently expressed this idea. For example, in United States - Continued Dumping and Subsidy Offset Act of 2000 (DS217), the Appellate Body stated: "Performance of treaties is also governed by good faith. Hence, Article 26 of the Vienna Convention, entitled Pacta Sunt Servanda, provides that every treaty in force is binding upon the parties to it and must be performed by them in good faith." ${ }^{, 79}$ Individual member states such 
as the US also affirmed: "WTO Members must uphold their obligations under the covered agreements in good faith." ${ }^{, 80}$ Clearly, the WTO agreements must be performed by its members in 'good faith.' A consensus has already been reached on this matter.

Regarding Article XXI (b), it not only grants discretion to members, but also sets conditions for members to abide by. Therefore, members must exercise these rights and obligations in 'good faith.' Despite the numerous debates at the GATT Council meetings, members unanimously agreed that member states should only invoke the exception in 'good faith. ${ }^{81}$ To date, the members show no sign of changing this attitude.

In addition, whether or not a member has acted in good faith is subject to judicial review. In United States - Continued Dumping and Subsidy Offset Act of 2000 (DS217), the US argued: "There is no basis or justification in the WTO Agreement for a WTO dispute settlement panel to conclude that a Member has not acted in good faith, or to enforce the 'good faith' principle as a substantive obligation agreed to by WTO Members. ${ }^{, 82}$ In response, the Appellate Body, recognizing the relevance of the principle of good faith in a number of cases, stated: "Clearly, therefore, there is a basis for a dispute settlement panel to determine, in an appropriate case, whether a Member has not acted in good faith." ${ }^{83}$ Therefore, whether or not a member invokes Article XXI (b) in 'good faith' can be subject to review by a WTO dispute settlement.

Last, a self-judging clause should nevertheless be governed by the principle of 'good faith.' This has been recognized by international case law. In Certain Questions of Mutual Assistance in Criminal Matters (Djibouti v. France), Djibouti acknowledged that the requested state (France) benefitted from a wide discretion in deciding to refuse mutual assistance because, according to Article 2 of the treaty in dispute, it is the requested state that "considers that execution of the request is likely to prejudice its sovereignty, its security, its ordre public or other of its essential interests." ${ }^{84}$ However, Djibouti contended, even in reliance on what it describes as a "self-judging clause," the requested state must act reasonably and in good faith. ${ }^{85}$ The International Court of Justice stated: “... while it is correct, as France claims, that the terms of Article 2 provide a State ... with a very considerable discretion, this exercise of discretion is still subject to the obligation of good faith codified in Article 26 of the 1969 Vienna Convention., ${ }^{, 86}$ 
Hence, a reference to the principle of good faith would be a prudent solution for reviewing an Article XXI (b) dispute. In this dispute, even the US has the discretion to impose steel and aluminum tariffs under Article XXI (b). Whether it has been acted in 'good faith' is still subject to the WTO review. The panel or the Appellate Body is capable of making merits as regards this matter.

\section{What are Some Possible Outcomes if the 'Good Faith' Standard is Applied to the US Tariff Measures in Dispute?}

If the good faith standard is applied to particular factual and legal circumstances of the US steel and aluminum tariffs, what are the possible outcomes? Are these measures taken in 'good faith'? The answer would be negative.

First, the US does not interpret Article XXI (b) in 'good faith.' As mentioned above, the US simply ignores the distinction between the language of Article XXI (a) and Article XXI (b) with special references to the three conditions listed in Article XXI (b) (i), (ii) and (iii). Its positions on the jurisdiction of Article XXI contradict each other. As its interpretation serves to defeat the object and purpose of Article XXI (b), there would be no balance if a member has full discretion to define what it considers necessary for the protection of its national security. Following this interpretation, Article XXI (b) would be widely open to misuse and abuse, which has exactly happened in this dispute.

Second, the US does not carry out its rights and obligations under Article XXI (b) in light of the 'good faith' principle. In this dispute, the various elements included in Article XXI (b) were not applied in 'good faith.' The interests at stake cannot reasonably or even plausibly be considered to be 'essential security' interests, as analyzed above. One of the reasons for the steel and aluminum tariffs is global excess capacity. The WTO offers some tools (e.g., safeguard measures and emergency measures) for members to handle this issue. Some members (e.g., the EU) also seek to apply safeguard measures to deal with it. ${ }^{87}$ However, only the US has chosen to impose global tariffs and invoke Article XXI for justification so that it can be exempted from the WTO review. This would be an indicator of the existence of bad faith, not 'good faith.'

Third, the standard of 'good faith' should be sufficiently clear to prohibit discriminatory actions. ${ }^{88}$ In this dispute, some states (e.g., South Korea) are granted permanent or temporary exemptions, ${ }^{89}$ while other states (e.g., Russia) are 
not. The non-equal treatment between members indicates that the US has violated the principle of 'good faith.'

Therefore, the US tariff measures have not been applied reasonably when considering both the WTO obligations of the US, and the legal rights of China and other members. This is clearly an abuse and misuse of security exceptions under Article XXI (b).

\section{Conclusion}

The US has, so far, been one of the most active users of Article XXI. Particularly, the Trump Administration appears to show no hesitation in invoking Article XXI to justify its restriction measures for the protection of domestic industries. On May 23, 2018, only two months after the imposition of the steel and aluminum tariffs, the US Secretary of Commerce initiated another investigation to determine whether imports of automobiles and automotive parts threatened to impair the US national security. ${ }^{90}$ If it happens, the US would most likely use Article XXI again as an excuse.

How should then the WTO tackle these threats before they cause substantial damage to the multinational trading system? The author argues the panel and/or the Appellate Body could at least conduct a 'good faith' review of the disputed US tariff measures, as discussed above, and then set a precedent for future cases. This will not be easy given the previous practice of Article XXI. However, subsequent complaints from India, the EU, Canada, Mexico, and Norway may increase the possibility of success. If more members become involved and submit complaints, the panel and/or the Appellate Body would face more pressure or have more incentives to take action as suggested above.

However, it is also possible that China may settle this dispute with the US itself. China and the US have conducted several negotiations around the US tariff measures and other issues. If Trump Administration recognizes what it wants from China, it may withdraw its tariff measures on Chinese-produced steel and aluminum. Mr. Trump could also be forced to take back its tariff measures due to domestic pressures. His protection measures may benefit some industries, but would also hurt others as well as the US consumers. The industries that are 
subjected to the retaliatory measures taken by China and other countries may blame Trump Administration. These industries may offer to help solve this problem. ${ }^{91}$

However, despite the above approaches, a definitive resolution is needed in order to bring clarification to the words of Article XXI and put an end to its abuse and misuse. Recently, the WTO members have unprecedentedly relied on Article XXI to justify their trade restriction measures. Since 2016, there have already been eleven disputes relating to Article XXI security exceptions. ${ }^{92}$ The GATT and the WTO have never seen this before. This pressures the WTO into setting a clear limit on the invocation of Article XXI before the situation goes beyond its control.

A lasting and acceptable solution is to seek proper interpretations of Article XXI. In 1982, the contracting parties of GATT 1947 adopted the "Decision Concerning Article XXI of the General Agreement." However, this has not been exceedingly effective. ${ }^{93}$ In 2015, Russia submitted a proposal to the Ministerial Conference, asking the members to engage in negotiations and the General Council to take a formal decision on an interpretation of Article XXI. ${ }^{94}$ Russia recommended: "The negotiations shall focus on identification of circumstances when application of the measures pursuant to Security Exceptions is justified, as well as provision of specific transparency requirements and possible retaliatory measures." ${ }^{95}$ Now is the time for the members and the General Council to take serious steps toward implementing this proposal.

\section{REFERENCES}

1. US Dept. of Commerce, The Effect of Imports of Steel on the National Security-An Investigation Conducted under Section 232 of the Trade Expansion Act of 1962 (2018), as Amended, available at $\mathrm{https} / / / \mathrm{www}$. commerce.gov/sites/commerce.gov/files/the_effect_of imports_of_steel_on_the_national_security_-_with_redactions_-_20180111.pdf (last visited on Aug. 16, 2018).

2. US Dep't of Commerce, The Effect of Imports of aluminum on the National Security: An Investigation Conducted under Section232 of the Trade Expansion Act of 1962 (2018), as Amended, available at https://www.commerce.gov/sites/commerce.gov/files/the_effect_of_ imports_of_aluminum_on_the_national_security_-_with_redactions__20180117.pdf (last visited April 28, 2018). 
3. Presidential Proclamation Adjusting Imports of Steel into the United States (Proclamation No. 9705), available at https://www.whitehouse.gov/presidential-actions/presidentialproclamation-adjusting-imports-steel-united-states-2; Presidential Proclamation Adjusting Imports of Aluminum into the United States (Proclamation No. 9704), available at https:// www.whitehouse.gov/presidential-actions/presidential-proclamation-adjusting-importsaluminum-united-states-2 (all last visited on Aug. 16, 2018).

4. United States - Certain Measures on Steel and Aluminium Products-Request for Consultations by China, WTO Doc. WT/DS544/1, G/L/1222, G/SG/D50/1 (adopted Apr. 9, 2018), available at https://docs.wto.org/dol2fe/Pages/FE_Search/FE_S_S009-DP.aspx?language=E \&CatalogueIdList=246042,246040,244782,244785,244724,244720,244658,244602,244375 $\&$ CurrentCatalogueIdIndex $=8 \&$ FullTextHash $=\&$ HasEnglishRecord $=$ True $\&$ HasFrenchRecor $\mathrm{d}=$ True \&HasSpanishRecord=True (last visited on Aug. 13, 2018).

5. United States - Certain Measures on Steel and Aluminum Products - Request to join consultations, WTO Doc. WT/DS544/3(adopted Apr. 18, 2018), WT/DS544/4 (adopted Apr. 19, 2018), WT/DS544/5 (adopted Apr. 19, 2018), WT/DS544/6 (adopted Apr. 23, 2018), WT/DS544/7 (adopted Apr. 23, 2018), available at https://www.wto.org/english/tratop_e/dispu_e/cases_e/ ds544_e.htm (last visited on Aug. 16, 2018).

6. United States - Certain Measures on Steel and Aluminum Products- Request for consultations by India, WTO Doc. WT/DS547/1 (adopted May 23, 2018), available at https://docs.wto.org/ dol2fe/Pages/FE_Search/FE_S_S006.aspx?Query=(@Symbol=020wt/ds547/*)\&Language= ENGLISH\&Context=FomerScriptedSearch\&languageUIChanged=true (last visited on Aug. 16, 2018).

7. United States - Certain Measures on Steel and Aluminum Products - Request for consultations by the European Union, WTO Doc. WT/DS548/1 (adopted June 6, 2018), available at https:// docs.wto.org/dol2fe/Pages/FE_Search/FE_S_S006.aspx?Query=(\%40Symbol\%3d+wt $\% 2 \mathrm{fds}$ $\left.548 \% 2 \mathrm{f}^{*}\right) \&$ Language $=$ ENGLISH $\&$ Context $=$ FomerScriptedSearch\&languageUIChanged $=\mathrm{tr}$ ue (last visited on Aug. 16, 2018).

8. United States - Certain Measures on Steel and Aluminum Products - Request for consultations by Canada, WTO Doc. WT/DS550/1 (adopted June 6, 2018), available at https://docs.wto. org/dol2fe/Pages/FE_Search/FE_S_S006.aspx?Query=(\%40Symbol\%3d+wt $\% 2 \mathrm{fds} 550 \% 2 \mathrm{f} *)$ \&Language $=$ ENGLISH\&Context $=$ FomerScriptedSearch\&languageUIChanged=true $\#$ (last visited on Aug. 16, 2018).

9. United State - Certain Measures on Steel and Aluminum Products - Request for consultations by Mexico, WTO Doc. WT/DS551/1 (adopted June 7, 2018), available at https://docs.wto. org/dol2fe/Pages/FE_Search/FE_S_S006.aspx?Query=(\%40Symbol\%3d+wt $\% 2$ fds551\%2f*) $\&$ Language $=$ ENGLISH $\&$ Context $=$ FomerScriptedSearch\&languageUIChanged $=$ true $\#$ (last visited on Aug. 16, 2018).

10. United States - Certain Measures on Steel and Aluminum Products - Request for consultations by Norway, WTO Doc. WT/DS552/1 (adopted June 19, 2018), available at https://docs.wto. 
org/dol2fe/Pages/FE_Search/FE_S_S006.aspx?Query=(@Symbol=\%20wt/ds552/*)\&Lang uage=ENGLISH\&Context=FomerScriptedSearch\&languageUIChanged=true\# (last visited on Aug. 16, 2018).

11. United States - Certain Measures on Steel and Aluminum Products- Request for consultations by the Russian Federation, WTO Doc. WT/DS554/1 (adopted June 29, 2018), available at https://docs.wto.org/dol2fe/Pages/FE_Search/FE_S_S006.aspx?Query=(@Symbol=\%20wt/ ds554/*)\&Language=ENGLISH\&Context=FomerScriptedSearch\&languageUIChanged $=$ tr ue\# (last visited on Aug. 16, 2018).

12. United States - Certain Measures on Steel and Aluminum Products - Request for consultations by Switzerland, WTO Doc. WT/DS556/1 (adopted July 12, 2018), available at https://docs. wto.org/dol2fe/Pages/FE_Search/FE_S_S006.aspx?Query=(@Symbol=\%20wt/ds556/*)\& Language $=$ ENGLISH\&Context $=$ FomerScriptedSearch\&languageUIChanged $=$ true $\#$ (last visited on Aug. 16, 2018).

13. United States - Certain Measures on Steel and Aluminum Products - Communication from the United States, WTO Doc. WT/DS544/2 (adopted Apr. 17, 2018), available at https://docs. wto.org/dol2fe/Pages/FE_Search/FE_S_S006.aspx?Query=(@Symbol=\%20wt/ds544/*)\&L anguage $=$ ENGLISH\&Context $=$ FomerScriptedSearch\&languageUIChanged $=$ true. See also Imposition of A Safeguard Measure by the United States on Imports of Aluminum, WTO Doc. G/SG/161/Suppl.1, G/SG/162/Suppl.1, G/SG/167 (adopted Apr. 4, 2018), available at https://docs.wto.org/dol2fe/Pages/FE_Search/.../G/SG/161S1.pdf (all last visited on Aug. 13, 2018).

14. Supra note 1 , at 23.

15. Id.

16. Supra note 2, at 24.

17. US Dept. of Defense, Memorandum for secretary of commerce: Response to Steel and Aluminum Policy Recommendations (2018), at 1, available at https://www.commerce.gov/ sites/commerce.gov/files/department_of_defense_memo_response_to_steel_and_aluminum policy_recommendations.pdf (last visited on Aug. 13, 2018).

18. Supra note 1, at 57. See also supra note 2, at 104.

19. Supra note 17.

20. See China-US Debate on AB, 232, 301 at the WTO General Council Meeting, available at https://mp.weixin.qq.com/s/R03cUfDJAxgkX87o_4mcQg (last visited on Aug. 13, 2018).

21. GATT 1994 art. XXI(b).

22. Supra note 1, at 50-1.

23. Supra note 17.

24. M. Hahn, Vital Interests and the Law of GATT: An Analysis of GATTs Security Exception, 12 Mich. J. INT'L L. 588 (1991).

25. Supra note 1 , at 16.

26. WTO Analytical Index: General Agreement on Tariffs and Trade (GATT), 1994, Article XXI 
(Security Exceptions), at 603, available at https://www.wto.org/english/res_e/publications_e/ ai17_e/gatt1994_art21_gatt47.pdf (last visited on Aug. 16, 2018).

27. Id.

28. Ji Yeong Yoo \& Dukgeun Ahn, Security Exceptions in the WTO System: Bridge or BottleNeck for Trade and Security? 19 J. InT'L Econ. L. 417 (2016).

29. US Responses to the Panel's and Russia's Questions to Third Parties (February 20, 2018) in Russia - Measures Concerning Traffic in Transit (DS512), available at https:/ustr.gov/sites/ default/files/enforcement/DS/US.3d.Pty.As.Pnl.and.Rus.Qs.fin.\%28public\%29.pdf (last visited on Aug. 13, 2018).

30. Supra note 26, at 600. See also UN ECOSOC, Verbatim Report: Thirty-Third Meeting of Commission, July 24, 1947, Geneva, available at https://docs.wto.org/gattdocs/q/UN/EPCT/ APV-33.PDF (last visited on Aug. 16, 2018). [Emphasis added]

31. EU Third Party Written Submission, in Russia - Measures Concerning Traffic in Transit (DS512), ๆ 50, available at http://trade.ec.europa.eu/doclib/docs/2018/february/tradoc_ 156602.pdf (last visited on Aug. 13, 2018).

32. Supra note 1 , at 13.

33. Id.

34. Id.

35. Id. at 2-5.

36. @realDonaldTrump, available at https://twitter.com/realdonaldtrump/status/969183644 756660224 (last visited Aug. 13, 2018).

37. @realDonaldTrump, available at https://twitter.com/realdonaldtrump/status/971726862 526361603 (last visited Aug. 13, 2018).

38. Supra note 13.

39. Imposition of A Safeguard Measure by the United States on Imports of Steel-Request for Consultations under Article 12.3 of the Agreement on Safeguards, WTO Doc. G/SG/162 (China) (adopted March. 26, 2018), available at https://docs.wto.org/dol2fe/Pages/FE Search/FE_S_S009-DP.aspx?language $=$ E\&CatalogueIdList $=244124,244064,244065,24406$ $6,244067,243902,243903,243799,243701,243647 \&$ CurrentCatalogueIdIndex=2\&FullText Hash=371857150\&HasEnglishRecord=True \&HasFrenchRecord=True\&HasSpanishRecord $=$ False (last visited on Aug. 18, 2018).

40. Id.

41. Supra note 20.

42. Supra note 13.

43. Imposition of A Safeguard Measure by the United States on Imports of Certain Steel and Aluminium Products, WTO Doc. G/SG/173(EU) (adopted Apr. 16, 2018), available at https://docs.wto.org/dol2fe/Pages/FE_Search/FE_S_S009-DP.aspx?language=E\&Catalo gueIdList $=244603,244605,244538 \&$ CurrentCatalogueIdIndex $=2 \&$ FullTextHash $=371857$ $150 \&$ HasEnglishRecord $=$ True $\&$ HasFrenchRecord $=$ True $\&$ HasSpanishRecord $=$ True (last 
visited on Aug. 13, 2018). See also WTO Doc. G/SG/177(India) (adopted Apr. 17, 2018), available at https://docs.wto.org/dol2fe/Pages/FE_Search/FE_S_S006.aspx?MetaCollection $=$ WTO\&SymbolList $=\&$ Serial $=\&$ IssuingDateFrom $=17 \% 2 \mathrm{f} 04 \% 2 \mathrm{f} 2018 \&$ IssuingDateTo $=17$ $\% 2 \mathrm{f} 04 \% 2 \mathrm{f} 2018 \&$ CATTITLE $=\&$ ConcernedCountryList $=\&$ OtherCountryList $=\&$ SubjectList $=\&$ TypeList $=\&$ FullTextHash $=371857150 \&$ ProductList $=\&$ BodyList $=\&$ OrganizationList $=\&$ ArticleList $=\&$ Contents $=\&$ CollectionList $=\&$ RestrictionTypeName $=\&$ PostingDateFrom $=\& P$ ostingDate $\mathrm{To}=\&$ DerestrictionDateFrom $=\&$ DerestrictionDate $\mathrm{T}=\&$ ReferenceList $=\&$ Langu age $=$ ENGLISH $\&$ SearchPage $=$ FE_S_S001\&ActiveTabIndex $=0$ \&languageUIChanged $=$ true (all last visited on Aug. 13, 2018).

44. Id.

45. Id.

46. See EU can retaliate immediately against Trump's metal tariffs, available at http://worldtradelaw. typepad.com/ielpblog/2018/03/eu-can-retaliate-immediately-against-trumps-metal-tariffs. html (last visited on Aug. 13, 2018).

47. P. van den Bossche, The Law and Policy of the World Trade Organization: Text, Cases AND Materials 636 (2005).

48. Panel Report, Indonesia - Safeguard on Certain Iron or Steel Products, ๆๆ 7.14-7.15, WTO Doc. WT/DS496/R (adopted July 6, 2018), available at https://www.wto.org/english/tratop_ e/dispu_e/cases_e/ds496_e.htm (last visited on Aug. 13, 2018).

49. Appellate Body Report, US - Line Pipe, $\mid$ 84, WTO Doc. WT/DS202/AB/R (adopted Feb. 15, 2002), available at https://docs.wto.org/dol2fe/Pages/FE_Search/FE_S_S009-DP.aspx?1 anguage $=\mathrm{E} \&$ CatalogueIdList $=90407,101670,68570,47846,43747,81812,36525,27772,5953$ $7,16664 \&$ CurrentCatalogueIdIndex $=7 \&$ FullTextHash $=\&$ HasEnglishRecord $=$ True $\&$ HasFre nchRecord $=$ True \&HasSpanishRecord $=$ True (last visited on Aug. 13, 2018).

50. Supra note 8.

51. Supra note 29.

52. Supra note 13.

53. In this dispute, Russia, with the support of the US, invoked Article XXI of the GATT 1994 for justification and alleged that Article XXI was not a justiciable provision. See supra note 29.

54. Supra note 29.

55. Responses of the United States of America to Questions From the Panel and Russia to Third Parties, in WTO Doc. WT/DS512, available at https:/ustr.gov/sites/default/files/ enforcement/DS/US.3d.Pty.As.Pnl.and.Rus.Qs.fin.\%28public\%29.pdf (last visited on Aug. 13, 2018).

56. Supra note 24, at 590.

57. Supra note $31, \mathbb{1} 40$.

58. TPP/CPTPP art. 29.2 (Security Exceptions). It provides: "Nothing in this Agreement shall be construed to: (a) require a Party to furnish or allow access to any information the disclosure 
of which it determines to be contrary to its essential security interests; or (b) preclude a Party from applying measures that it considers necessary for the fulfilment of its obligations with respect to the maintenance or restoration of international peace or security, or the protection of its own essential security interests."

59. Supra note $31, \boldsymbol{\Phi} 14$.

60. Supra note 47, at 188.

61. Supra note 31, ๆ 14.

62. Supra note 8.

63. Supra note $6 \& 9$.

64. Id.

65. Panel Report, United States - Trade Measures Affecting Nicaragua 9 4.9, WTO Doc. WT/ L/6053, (unadopted), available at https://www.wto.org/english/tratop_e/dispu_e/gatt_ e/85embarg.pdf (last visited on Aug. 13, 2018).

66. Supra note $31, \llbracket 20$.

67. S. Malawer, Trump, Trade and National Security, 259 N.Y.L.J. (2018), available at https:// www.law.com/newyorklawjournal/2018/03/23/trump-trade-and-national-security (last visited on Aug. 13, 2018).

68. Id.

69. J. Fahner, Qatar under Siege: Chances for an Article XXI Case?, available at https://www. ejiltalk.org/qatar-under-siege-chances-for-an-article-xxi-case (last visited on Aug. 13, 2018).

70. These interpretations were summarized by Roger P. Alford as follows: "According to one interpretation, a Member State can decide for itself whether a measure is essential to its security interests and relates to one of the enumerated conditions. Another interpretation would recognize a Member State's prerogative to determine for itself whether a security exception is applicable, but would impose a good faith standard that is subject to judicial review. Under a third interpretation, a Member State can decide for itself whether 'it considers' a measure to be 'necessary for the protection of its essential security interests,' but the enumerated conditions are subject to judicial review." See R. Alford, The Self-Judging WTO Security Exception, 3 Utah L. Rev. 704 (2011).

71. Supra note 69.

72. A. Mitchell, Good Faith in WTO Dispute Settlement, 7 Melb. J. Int'L L. 339 (2006).

73. Appellate Body Report, United States - Import Prohibition of Certain Shrimp and Shrimp Products, I 158, WTO Doc. WT/DS/58/AB/R (adopted Oct. 12, 1998), available at https:// docs.wto.org/dol2fe/Pages/FE_Search/FE_S_S009-DP.aspx?language=E\&CatalogueIdList $=58544 \&$ CurrentCatalogueIdIndex $=0 \&$ FullTextHash $=\&$ HasEnglishRecord $=$ True $\&$ HasFre nchRecord $=$ True $\&$ HasSpanishRecord $=$ True (last visited on Aug. 13, 2018).

74. S. Reinhold, Good Faith in International Law, 2 UCL J. L. \& JuRISPRUdence 40 (2013).

75. Supra note 73.

76. Supra note 72. 
77. DSU art. 3(2).

78. WTO Analytical Index: DSU-Article 3 (Jurisprudence), ๆๆ 16-17, available at https://www. wto.org/english/res_e/publications_e/ai17_e/dsu_art3_jur.pdf (last visited May 30, 2018).

79. Appellate Body Report, United States-Continued Dumping and Subsidy Offset Act of 2000, 『 296, WTO Doc. WT/DS217/AB/R (adopted Jan. 16, 2003), available at https://docs.wto. org/dol2fe/Pages/FE_Search/FE_S_S009-DP.aspx?language $=$ E\&CatalogueIdList=8896\&C urrentCatalogueIdIndex $=0 \&$ FullTextHash $=\&$ HasEnglishRecord $=$ True $\&$ HasFrenchRecord $=$ True\&HasSpanishRecord=True (last visited on Aug. 13, 2018).

80. Id.

81. Supra note 70.

82. Supra note 79, ๆ 28.

83. Id. $ๆ 297$.

84. Certain Questions of Mutual Assistance in Criminal Matters (Djibouti v. Fr.), Judgment, 2008 I.C.J. Rep. I 135 (June 4), available at https://www.icj-cij.org/files/case-related/136/ 136-20080604-JUD-01-00-EN.pdf (last visited on Aug. 13, 2018).

85. Id.

86. Id. $\uparrow 145$.

87. European Commission, Notice of initiation of a safeguard investigation concerning the imports of steel products, OfFICIAL J. E.U. (C 111/29), Mar. 26, 2018, available at https://eurlex.europa.eu/legal-content/EN/TXT/PDF/?uri=OJ:JOC_2018_111_R_0010\& from=EN (last visited Aug. 13, 2018).

88. W. Cann, Jr., Creating Standards and Accountability for the Use of the WTO Security Exception: Reducing the Role of Power-Based Relations and Establishing a New Balance Between Sovereignty and Multilateralism, 26 Y ALE J. InT'L L. 452 (2001).

89. USTR, Joint Statement by the United States Trade Representative Robert E. Lighthizer and Republic of Korea Minister for Trade Hyun Chong Kim, available at https:/ustr.gov/aboutus/policy-offices/press-office/press-releases/2018/march/joint-statement-united-states-trade (last visited Aug. 13, 2018).

90. US Department of Commerce Initiates Section 232 Investigation into Auto Imports, available at https://www.commerce.gov/news/press-releases/2018/05/us-department-commerceinitiates-section-232-investigation-auto-imports (last visited on Aug. 13, 2018).

91. Two suits have been brought by US industries before the US Court of International Trade to challenge the US tariff measures. One was filed by Severstal Export GMBH and Severstal Export Miami Corporation, seeking to enjoin the enforcement of Presidential Proclamation No. 9705. No award has been rendered yet, but the Court has declined to issue a preliminary injunction. See Severstal Export Gmbh and Severstal Export Miami Corporation v. United States of America, United States Customs And Border Protection, Acting Commissioner Kevin K. Mcaleenan, Department of Commerce, Secretary Wilbur Ross, and President Donald J. Trump, No. 18-00057, Slip Op. 18-37 (Ctr. Int'1 Trade April 5, 2018), available 
at https://www.cit.uscourts.gov/SlipOpinions/Slip_op18/18-37.pdf. The other was brought in June 2018 by the American Institute for International Steel, Inc.; Sim-Tex LP; and Kurt Orban Partners, LLC. In the complaint, the plaintiffs sought a declaratory judgment that Section 232 is "unconstitutional as an improper delegation of legislative power to the President, in violation of Article I, section 1 of the Constitution and the doctrine of separation of powers and the system of checks and balances that the Constitution protects." See American Institute for International Steel, Inc., Sim-Tex, Lp, and Kurt Orban Partners, LLC v. United States and Kevin K. Mcaleenan, Commissioner, United States Customs and Border Protection, No. 18-00152, available at http://worldtradelaw.typepad.com/files/ compaint-1.pdf (all last visited on Aug. 13, 2018).

92. In 2016, Ukraine requested a consultation with Russia regarding alleged multiple restrictions on traffic in transit (DS512). Russia referred to Article XXI as an excuse. In 2017, Ukraine made a second request for consultations with Russia regarding measures that concerned the transit of products (DS532). It is expected that Russia would again invoke Article XXI for justification. In the same year, Qatar requested three consultations with the United Arab Emirates (DS526), the Kingdom of Bahrain (DS527), and the Kingdom of Saudi Arabia (DS528), with respect to trade embargos imposed by these three countries. The United Arab Emirates has explicitly referred to the security exceptions of the GATT 1994. Regarding the US tariff measures at issue, by the end of June 2018, eight disputes have been brought against the US, as described in the beginning of this article. The United States has invoked and will invoke Article XXI for justification. Among these disputes, the panel has been established in dispute DS512 and is expected to issue its final report by the end of 2018. The panel also has been established in dispute DS526, but no panel has been established in any other dispute. All information related to this can be accessed on the WTO website.

93. Supra note 26, at 605-6.

94. Proposal on MC10 Ministerial Declaration - Part III, WTO Doc. WT/MIN(15)/W/14 (dated Nov. 13, 2015), available at https://docs.wto.org/dol2fe/Pages/FE_Search/ExportFile.aspx? $\mathrm{id}=135846 \&$ filename=q/WT/MIN15/W14.pdf (last visited on Aug. 13, 2018).

95. Id. 